\title{
Czy mit poddaje się parodii? Pacho, hybský zbojník (1975) Martina Ťapáka
}

W połowie lat 7o. prasa słowacka donosiła $\mathrm{z}$ entuzjazmem, że oto narodziła się prawdziwie słowacka komedia. Przy próbie rekapitulacji osiągnięć tego gatunku stwierdzono, że dotychczas przyniósł on jedynie nieśmiałe próby stworzenia czegoś swojskiego, charakterystycznego jedynie dla rodzimej kultury:

[...] pierwszy raz w historii filmu słowackiego powstało dzieło, które jest parodią tematyki zbójnickiej, ale przede wszystkim film wyjątkowy, z łagodną ironią wyśmiewający się z naszych cech charakteru. Legenda zbójnicka posłużyła [...] jako pretekst, by się nad nimi zaśmiać[1].

Warto na wstępie zapytać, czy jest to parodia czy satyra, co właściwie jest jej przedmiotem? Mit o Janosiku czy legenda zbójnicka? Na potrzeby poniższych rozważań przyjmę rozróżnienie zaproponowane przez Franciszka Ziejkę, dotyczące mitów i legend związanych z polską warstwą chłopską, adekwatne, w mojej opinii, w odniesieniu do bliskiej nam kultury. Mit - mówi F. Ziejka - w przeciwieństwie do legendy, która obrócona jest w przeszłość,

[...] zwraca się ku przyszłości, jego zadaniem jest takie a nie inne ukształtowanie myślenia, narzucenie takiego a nie innego programu [...] [termin odnosi się do] idei powstałej w określonych warunkach, jako wyraz społecznego zapotrzebowania, będącej wyobrażeniem, najczęściej fałszywym, o rzeczywistości społecznej, politycznej lub kulturowej[2].

Czy film Pacho parodiuje Janosika, postać historyczną, która stała się synonimem zbójnika nie tylko dla Słowaków? Na to nie poważyliby się zapewne twórcy filmu i nikt by tego od nich nie oczekiwał. Janosik pozostanie silny, nieustraszony, a z pewnością piękny i młody - kiedy go w okrutny sposób powieszono w Liptowskim Mikulaszu, miał 25 lat. Wśród krytyków przeważa opinia, że twórcy filmu parodiowali raczej samą legendę zbójnicką. Filmowy Pacho, rozbójnik hybski (z miejscowości Hybe), który nie ma historycznego pierwowzoru, przypomina Janosika z Terchowej bodaj jedynym rysem okrada bogatych. Jest zwykłym wieśniakiem, obdarzonym chłopskim rozumem, który jest jedyną jego bronią. Jako taki silnie przeciwstawia

[1] E. Kincelová, Narodila sa slovenská veselohra, „Práca” 1976, 18 czerwca, s. 6.

[2] Opowieść o powstaniu chłopskim, według badacza, nie jest sama w sobie mitem. Przeradza się w mit z chwilą, „gdy pojawi się przekonanie - idea, że wystarczy, by lud wziął w swe ręce broń, a ojczyzna będzie wolna", F. Ziejka, $W$ kręgu mitów polskich, Wydawnictwo Literackie, Kraków 1977, s. 8; zob. także tegoż autora: Złota legenda chłopów polskich, Państwowy Instytut Wydawniczy, Warszawa 1984. 
się typowi postaci Janosika, mocno zakorzenionemu już w kulturze filmowej Czechosłowacji. Jej twórcą był Palo Bielik - najpierw jako aktor, odtwórca roli Janosika w filmie Martina Friča, a po latach jako reżyser filmu o tymże zbójniku. Bielikowi, który długo pracował nad tym, by ugruntować legendę o Janosiku, prawdopodobnie nie podobał się film Pacho, hybský zbojnik. Długoletnie starania o potwierdzenie żywotności tradycji próbowała podważyć parodia w reżyserii Ťapáka. Czy była to udana próba? Co z sobą przyniosła?

Tradycja

Tradycja sięgała początków kina słowackiego - pierwszym pełnometrażowym filmem był wszak Jánošík (1921) w reżyserii Jaroslava Siakel’a i współpracującego z nim jego brata Daniela, słowackich emigrantów w USA, którzy sięgnęli po rodzimy temat. Projekt filmu o Janosiku już od połowy lat 20. nosił w sobie również twórca wspaniałego poematu dokumentalnego Ziemia śpiewa - etnografi filmowiec Karol Plicka[3]. To on właśnie odkrył Palo Bielika - jeszcze jako aktora-amatora - podczas konkursu teatralnego w Martinie w listopadzie 1932 roku. Bielik grał tam Janosika w amatorskiej inscenizacji Hôrni chlapci. Trzy lata później Plicka polecił Bielika Martinowi Fričowi jako głównego bohatera do filmu Janošík (1935). Pewne szczegóły narracyjne filmów o Janosiku stopiły się z jego legendą i funkcjonowały w świadomości Słowaków jako jej elementy, co potwierdzali etnografowie[4].

Petra Hanáková, autorka monografii Bielika, zauważa: Palo Bielik miał wszystkie potrzebne do tej roli atrybuty: charyzmę, był „wysoki niczym jodła” i wysportowany. Stał się - podobnie jak jego bohater wyrazem tego, czego w narodzie brak. Był idealną projekcją narodową, żywym mitem[5]. Autorka wskazuje również, że Fričowy Janosik zaczął funkcjonować jako rodzaj „materiału propagacyjnego, którego potencjał ideologiczny ciągle trwa, w nowych kontekstach stale się aktualizuje” [6]. Sam casting to filmu Friča obrósł legendą: Bielik wspomina, że oglądano go niczym konia, kazano biegać, skakać, rzucać polanami. Wybierano nie aktora, lecz typ, który był zgodny z wyobrażeniami o silnym, atletycznym góralu[7]. Hanáková wskazuje na wpływ, jaki wywarł aktor na koncepcję przyszłego filmu: gdy Bielik pokazał, jak rzuca ciupagą i biega, Frič zaczął skreślać dialogi w scenariuszu, aby zaakcentować główną postać i jej działanie[8]. Jest to niezmiernie ciekawa okoliczność w kontekście późniejszego filmu Pacho, hybský zbojnik: i tutaj sama postać odtwórcy tytułowej roli wpłynęła na scenarzystę.

[3] M. Slivka, Karol Plicka - Básnik obrazu, vyd. 2, Osveta, Martin 1999, s. 144-145.

[4] Mówiono o tym podczas seminarium, które odbyło się w październiku 2000 roku w ramach festiwalu Etnofilm w Čadcy, poświęconego tematowi Janosika w filmie.

[5] P. Hanáková, Palo Bielik a slovenská filmová kultúra, Slovenský filmový ústav, Bratislava 2010, s. 16.

[6] Ibidem, s. 28.

[7] Bielik i Ivan Július Kovačevič to dwie osobowości, którym zawdzięcza się fundamenty kinematografii narodowej. V. Macek, J. Paštéková, Dejiny slovenskej kinematografie, Osveta, Martin 1997, s. 59.

[8] Podaję za: P. Hanáková, op. cit., s. 18. Był to ostatecznie „film akcji”. Bardziej niż o niuanse psychologiczne chodziło w nim o przedstawienie walki dobra ze złem, samotnego bohatera i aroganckiej władzy. Ponieważ władzę reprezentowali tu feudałowie węgierscy, stąd protesty Węgrów przeciwko pokazaniu filmu w Wenecji (był tam pokazany w roku 1936). 
Bielik, który „w filmie nie zagrał [...], wystarczyła jego fotogeniczność" [9], stał się sławny. Film był wyświetlany na festiwalu w Wenecji, pokazywano go w ponad czterdziestu krajach. Rola przylgnęła do aktora. Temat był mu bliski, nawet w pewien sposób go naznaczył, kiedy już jako reżyser - po ważnym zresztą epizodzie z filmem dokumentalnym w czasie Pierwszej Republiki Słowackiej - zaczął realizować własne fabuły. Taka jest geneza późniejszej, trzeciej wersji legendy filmowej o Janosiku. Dwuczęściowy film Bielik zaczął przygotowywać już w roku 1951[10], wtedy realizacja okazała się niemożliwa. Drugą próbę miał podjąć jeszcze pod koniec lat 50., przed fabułą o kapitanie Dabaczu (Bunt kapitana, 1959). Czy dlatego obdarzył kapitana, przyłączającego się do Słowackiego Powstania Narodowego, rysami legendarnej postaci? Jako negatywne cechy filmu wymieniano bowiem: „zbyt wielką dawkę romantyzmu, pijatyki, działania «janosikowskie»"[11]. W filmach Bielika oglądamy przede wszystkim pełnokrwiste, męskie charaktery, mocne indywidualności, charyzmatycznych, choć osamotnionych, przywódców. Nawet przeciwnik polityczny kapitana Dabacza nakreślony jest jako silna i zasługująca na respekt postać.

Warto przyjrzeć się genezie filmu Bielika także od strony produkcyjnej, ponieważ ona wyjaśnia nie tylko jego rozmach, ale i przesłanie. Okazją do ostatecznego sfinalizowania długoletnich zamierzeń stała się 250. rocznica śmierci Janosika. Rozmach projektu godny był tematu, ale również - może nawet przede wszystkim - niezwykle silnej, wyraźnie uprzywilejowanej pozycji Bielika w kinematografii słowackiej. Jako aktor jeszcze przed wojną stał się pierwszą gwiazdą filmu, to zaś zapewniło mu angaż w Teatrze Narodowym w Bratysławie. W czasie wojny (państwa słowackiego), realizując dokumenty, przysłużył się do rozwoju kinematografii słowackiej - choć to może kwestia kontrowersyjna - jednak kontrowersje w tym względzie zatuszowało uczestnictwo w powstańczym „sztabie filmowym” słowackiego powstania narodowego. Niedoszły autor planowanego wówczas filmu Odboj 44 (Opór 44) był więziony aż do nadejścia Armii Czerwonej. Zdjęcia dokumentalne nakręcone podczas powstania umożliwiły mu z kolei realizację filmu Za slobodu (Za wolność, 1944-1945) już w nowych warunkach politycznych. Po wojnie zrealizował z Fričem pierwszą fabułę słowacką, a później pierwszy samodzielny pełnometrażowy film Wilcze doły (1948). Również pierwsza fabuła, która powstała w wybudowanych właśnie atelier bratysławskich na Kolibie, była dziełem Bielika (W piątek trzynastego, 1953).

Autorka monografii Bielika wskazuje, że do roku 1966 był on jedynym reżyserem, którego twórczość, od strony produkcyjnej, wykazywała bilans dodatni. Do tego roku jego filmy zarobiły 13,5 mln koron; Bielik jako jedyny miałby szanse funkcjonować w kapitalizmie[12]. W tym kontekście nie dziwi może fakt, że pierwszeństwo przysługiwało mu także podczas realizacji wymarzonego projektu o Janosiku: owa
[9] P. Hanáková, op. cit., s. 21.
[11] P. Hanáková, op. cit., s. 152.
[10] V. Macek, J. Paštéková, op. cit., s. 130.
[12] Ibidem, s. 178. 
superprodukcja była pierwszym panoramicznym i barwnym filmem, składającym się z dwóch części (obie kosztowały razem ponad $10 \mathrm{mln}$ koron, gdy przeciętny film realizowany wówczas na Słowacji bywał trzykrotnie tańszy). Zgodnie z zamierzeniem miała to być „historia wiarygodna, aktualizowana, na nowo interpretowana legenda narodowa, oczyszczona z elementów cudowności”[13]. Główną rolę powierzono amatorowi Františkowi Kuchcie, którego cechy - „wygląd bohatera filmu akcji, odważne, ale jednocześnie skromne wejrzenie” - były tymi właśnie, których Bielikowi w filmie Friča nieco brakowało[14]. Jako reżyser Bielik dodaje swemu bohaterowi - czy też wydobywa z odtwórcy jego roli - cechy raczej ludzkÍie niż heroiczne, dzięki czemu staje się on postacią bardziej wiarygodną. Reżyser racjonalizuje wyobrażenia o nadzwyczajnych zdolnościach przywódcy, który w jego dziele staje się surowym wodzem znakomicie zorganizowanych zbójników - właściwie jest to całe podziemne państwo, w którym obowiązuje reżim wojskowy. W filmie zwracają uwagę przemyślne urządzenia i machiny (są czymś więcej niż elementami rozbudowanej scenografii), które mają ułatwiać żywot w górach i obronę na wypadek ataku. Pomiędzy tymi urządzeniami uwijają się członkowie drużyny.

Kto jest ich przeciwnikiem? Feudałowie, których najpotworniejszym wcieleniem jest Aurel Žurayi, charakteryzowany jako sadysta polujący na młodą zwierzynę, ale i na człowieka. Zarzucano reżyserowi, że popadł w schematyzm socrealistyczny, połączył go w jednym dziele z elementami filmu przygodowego: postacie feudałów są nakreślone karykaturalnie, mają cechy niczym z podręcznika o walce klasowej, bynajmniej nie wzbogacają obrazu „historycznej zbędności” tej klasy[15].

Figura antybohatera

Pacho ist nie ein klein Mensch. Er ist ein Ozruta! Ein Slowakisch Herkules!

z filmu Pacho, hybský zbojnik

Jednego z członków drużyny Janosika grał w filmie Bielika Josef Kroner (Uhorčík - ojciec, w rolę młodszego Uhorčíka wcielił się właśnie Ťapák, późniejszy reżyser Pacha). Kroner nie miał za sobą studiów aktorskich i - jak poprzedni odtwórcy ról Janosika - wywodził się z teatru amatorskiego. Zbiegiem okoliczności, albo szczególnym trafem, po raz kolejny postać aktora rzutowała na kształt scenariusza filmowego. Frič skracał dialogi w scenariuszu, by ukazać Bielika raczej w akcji, po latach Bielik zaangażował Františka Kuchtę ( 203 cm wzrostu), który w filmie miał przede wszystkim być - całą swą postacią, jasnym wejrzeniem, naturalnością zachowania i brakiem tremy zasłaniał niedostatki rzemiosła aktorskiego (z zawodu był chirurgiem). Z kolei na scenarzystę Pacha i nakreślenie jego postaci jako parodii zbójnika wpłynęły poprzednie role Kronera, typy figur, jakie odtwarzał. Charakterystyczny jest fakt,

[13] V. Macek, J. Paštéková, op. cit., s. 173.

[14] Jánošík, I., II., „Česko-Slovenská filmová

databáze" [online], dostępna na stronie: $<$ http://www. csfd.cz/film/84727-janosik-i-ii/> [dostęp:

14 sierpnia 2013].

[15] V. Macek, J. Paštéková, op. cit., s. 173. 
że w prasie z lat 70., która wiele uwagi poświęcała jego głównej roli w filmie Ťapáka, nie wspomina się o największej z kreacji aktorskich Kronera w nagrodzonym Oscarem Sklepie przy głównej ulicy. Wiele z jego ról scenicznych i filmowych, w tym te wielkie, dosyć trafnie określa następująca charakterystyka: „pestré variáce veselých ludkov neurčitého veku [bogate wariacje na temat wesołych ludzików w nieokreślonym wieku]"[16]. Niezależnie od swych możliwości aktorskich utożsamiał się w swych rolach do pewnego stopnia $\mathrm{z}$ „czystą i szczerą duszą", choć czasem tragicznie zagubioną pośród mechanizmów rządzących światem.

Pacho w interpretacji Kronera stanowi parodię utrwalonych przez kino wyobrażeń na temat przywódcy zbójników - można rzec od pierwszego wejrzenia. Gdy po wojażach wraca do domu[17], pierwszy napotkany przez niego krajan czyni złośliwą aluzję do jego niskiego wzrostu: „Ty podrosłeś” (Pacho wygląda na około 50-latka[18], nie jest więc pacholęciem, które mogłoby jeszcze podrosnąć). Kiedy zaś przybysz zstępuje z pagórka, na który wcześniej wszedł, słyszy: „Ani tak bardzo nie...” Temat nikczemnego wzrostu tytułowego bohatera wraca za każdym razem, gdy otoczenie oczekuje potwierdzenia legendy o potężnym i silnym łupieżcy. Charakterystyczna jest scena, w której feudałowie piszą list do cesarzowej z prośbą o ochronę przed zbójnikiem: „Napiszcie, że to potężny chłop, to będzie wiarygodne. A silny niczym dwa szwadrony”. Takim chcą go oglądać damy - żony feudałów, żądne urozmaicenia nudnej egzystencji w swych zamkach, a nawet cesarzowa Maria Teresa. $Z$ takim przeciwnikiem spodziewają się walczyć wysłane przez cesarzową oddziały wojska i takiego chcą osadzić w twierdzy. Osadzą na koniec w Spielbergu całą drużynę z wyjątkiem Pacha, którego najpierw zignorują, a wreszcie zakopią po szyję w ziemi: "Jesteś mały, a będziesz jeszcze mniejszy".

W jaki zatem sposób Pacho został hersztem zbójników? Podczas pierwszej konfrontacji z nim zbójcy natrząsali się zwłaszcza z jego wzrostu i ogólnie mizernej postawy: „Wysoki jak jodła, mięśnie - jakby go jedna matka miała.... Nie ma nawet porządnej broni, jedynie składany nożyk. Gdy i ten rekwizyt wyśmiała cała drużyna, w Pachu jakby coś się przełamało: ogłasza, że może przystać do drużyny, ale tylko jako jej kapitan. Próbę sił z aktualnym wodzem ukazano w filmie za pomocą hiperbolizacji mocy chuderlawego Pacha. Jedno jego kichnięcie starczy, by położyć na ziemię wszystkich zbójników, drugie kichnięcie jest w stanie złamać potężne drzewo. Nadprzyrodzony talent Pacho objawia, uciszając śpiew ptaków. Przychodzi czas na próbę typowo męskich, lokalnych zdolności. Aktualny wódz rywalizuje z pretendentem „do tronu” o to, który z nich ma mocniejszą głowę do

[16] Jozef Kroner, „Česko-Slovenská filmová databáze" [online], dostępna na stronie: <http://www. csfd.cz/tvurce/952-jozef-kroner/> [dostęp: 22 października 2013].

[17] Konwencja filmu o Janosiku zakłada cztery zasadnicze części: 1. Powrót, 2. Objęcie przywództwa, 3. Żywot zbójników, 4. Zdrada.

[18] Kroner - jego odtwórca, rocznik 1924, przekroczył wówczas pięćdziesiątkę. 
alkoholu. Beczka, choć większa pojemnościowo, zawiera słabszy trunek, mniejsza beczułka - odpowiednio silniejszy. Po wypiciu jednym tchem całej zawartości Pacho pyta zbójników: „Mocniejszej nie macie?” Po tej próbie, przypieczętowanej jeszcze wychyleniem lokalnej „palenki” (na użytek filmu autorzy wymyślili jej mocniejszą wersję o nazwie „frndžalica”, będzie ona miała później niezastąpioną wartość bojową), zostaje już kapitanem, co potwierdza trzecim kichnięciem, sprowadzającym błyskawice.

Przywódcze talenty i przymioty nowego wodza zbójników są także pożywką dla rosnącej na dworach feudałów legendy o jego atrakcyjności erotycznej. Ten właśnie aspekt opowieści stanie się również główną przyczyną klęski Pacha, kiedy ten odrzuci względy samej cesarzowej. Przesadne koloryzowanie obrazu bohatera jako „pierwotnej siły" jest ważnym składnikiem parodii filmowej. Motyw powraca kilkakrotnie, nabierając mocy. Hrabia Erdődy charakteryzuje jeszcze Pacha przed małżonką jako „nic szczególnego, prymitywną siłę”. Aby jednak uatrakcyjnić swoje i hrabiny życie seksualne, przebiera się za zbójnika, a zostaje zdemaskowany tylko dlatego, że nie ma owłosionej piersi. Kiedy sława Pacha dotarła na dwór wiedeński, cesarzowa wzywa pracującego tam murarza z Liptova, z którym, jak widać, jest w dość poufałej relacji. Ten zapewnia Marię Teresę, że Pacho jest mocniejszym od niego mężczyzną, ,a nos ma dwa razy większy”. Im bardziej zagęszcza się atmosfera wokół Pacha, tym mniej wyszukane aluzje towarzyszą jego charakterystyce jako „prawdziwego mężczyzny”. Obdarzenie go nadzwyczajnymi zdolnościami w kilku dziedzinach ma zapewne wynagrodzić rzeczywiste (już nie urojone) niepowodzenia życiowe. Pacho zostaje bowiem kilkakrotnie pognębiony i upokorzony jako mężczyzna: własny ojciec policzkuje go przed towarzyszami, ukochana Hanka - której przez lata dochowuje wierności (ucieka przed hrabiną, która chciała go „zhańbić”) - znajduje sobie innego. Tę zdradę jednak tłumaczy mu się „klasowo”: „Panowie są wszystkiemu winni”. Pacho poprzysięga im zemstę.

Pacho przewodzi drużynie zbójników, która charakteryzowana jest jako zbieranina dość różnych żywiołów, przeważnie jednak są to ludzie prości, by nie powiedzieć: prymitywni, mało rozgarnięci i w gruncie rzeczy tchórzliwi. Niby są zbójcami, ale dopóki nie podpalają zamków i kaszteli - właściwie nikt się ich nie boi. W kontekście ich widocznego mazgajstwa skonstruowanie przez nich machin do rozniecania pożarów wydaje się przekraczać możliwości ich wyobraźni[19]. Można ich wyprowadzić w pole za pomocą dziecinnych forteli, czego dowiódł Pacho. Jako drużyna nie posiadają koni, choć kilkakrotnie pada komenda: „Na koń!“ Grupa bez wodza jest zupełnie słaba, bezsilna, a sam wódz - jest wszak zmitologizowany.

[19] Czy te przemyślne urządzenia nie miały być parodią skomplikowanych technicznych konstrukcji ukazanych w filmie Bielika? 
Wojsko cesarzowej - czyli „drużyna” przeciwnika - nie jest lepsze, nie grzeszy większą odwagą ani rozumem. Tak je charakteryzują twórcy filmu w kapitalnej scenie narady sztabowej. Oficerowie okazują się ciemni niczym tabaka w rogu i nie są w stanie pojąć planu taktycznego, rozrysowanego przez ich dowódcę (znakomita rola reżysera Juraja Herza). Generał wskazuje: „Wir sind, HIER! Pacho und seine räuberische pakáž ist HIER! Verststehen Sie, meine Hern!” Panowie oficerowie: „NEIN!” Generał: „ALSO NOCH EINMAL! Wir sind, HIER!...”

Zbójnicy rabują „bogatych”, ale niekoniecznie oddają łupy „biednym". Choć film ukazuje wyraźnie, że konflikty opisanego świata mają charakter klasowy, biedni nie bardzo zasłużyli sobie na lepszy los. Lud odmalowany w filmie Ťapáka ma najwyraźniej niewolniczą mentalność, której przejawy autorzy poddają wyraźnej hiperbolizacji. Pacho jest na przykład świadkiem sytuacji, w której pan bije chłopa. Chłosta odbywa się jednak zgodnie z rytuałem, ustalonym przez bijącego i przyjętym przez okładanego, o czym przekonuje się Pacho, chcący ratować biedaka z opresji. Chłop wyrywa mu z rąk batog i wręcza go na powrót swemu oprawcy. Towarzyszy temu jeden z kultowych dialogów filmu: „Daj ten bicz” - „Nie dam bicza” - „Daj ten bicz” - „Nie dam bicza”.

W każdej z wymienionych wyżej słowackich wersji legendy zbójnickiej prawdziwym przeciwnikiem, dręczycielem i przyczyną nieszczęść jest węgierska szlachta. W filmie Ťapáka charakteryzowana jest w sposób karykaturalny - jako warstwa, która nie przetrwałaby, gdyby nie opieka dworu cesarskiego. Od prawdziwej degeneracji chroni ją jedynie zmieszanie się ze zdrowym żywiołem zbójnickim, co w filmie ukazane jest $\mathrm{z}$ wymiernymi skutkami (płacz dzieci, których sporo przyszło na świat w wyniku tego zmieszania, przeszkadza w naradzie panom, niebędącym ich ojcami). Przedstawiciele największych węgierskich rodów - wymienione są nazwiska: Batory, Esterhazy, Palfi i Erdődy (w tej roli Marian Labuda) - piszą petycję i udają się do zbójników z prośbą, aby ci nie puścili z dymem reszty ich posiadłości. Wizyta jest źródłem wielu komicznych sytuacji, zasadzających się na parodiowaniu etykiety dworskiej, jakiej do pewnego momentu chcą sprostać gospodarze, salonowej konwersacji, ale i „niewymuszonej” wymiany zdań, którą współcześnie mogą prowadzić turyści w górach.

Zasadą organizującą film stała się w wielkiej mierze choreografia - gdyby reżyser oparł się tylko na niej, powstałoby dzieło na owe lata eksperymentalne, choć kto wie, czy spotkałoby się z tak gorącym przyjęciem. Ťapák - w jednej osobie aktor (wspomniana rola Uhorcika młodszego u Bielika, gdzie był też współreżyserem), scenarzysta, tancerz i choreograf - wprowadził do filmu układy choreograficzne, które zyskały wymiar komiczny, choć z tragicznym czasem podtekstem: obraz pracy pańszczyźnianej w rytm muzyki czy przywiązywania więźniów do drzewa. Wybitnie parodystyczny charakter mają sceny tańca, a to dzięki zderzeniu konwencji dworskiej z ludową. Kiedy łupem zbójników zamiast spodziewanych dukatów padają kosze ze strojami na bal, jest to pretekst, by „pokazać tym z Wiednia, jak się gra do tańca”. 
Zderzenie elementów tańców dworskich pomieszanych z ludowymi, gdy w tle słychać muzykę góralską, powoduje, że jedna konwencja staje się parodystycznym zwierciadłem drugiej. Podobny efekt powstaje w scenie odwiedzin feudałów w jaskini zbójców, którzy w celu rozgrzania atmosfery porywają do tańca damy. Na uwagę zasługuje występ solowy Mariana Labudy jako hrabiego, który w przebraniu Pacha wywija hołubce na pokojach swego zamku i w ferworze tańca wbija $\mathrm{z}$ rozmachem ciupagę $\mathrm{w}$ drzwi pięknej szafy.

\section{Źródła parodii}

[20] P. Hanáková, op. cit., s. 173-174.

[21] Paradoksalnie jako autorów najdroższych produkcji w kinematografii słowackiej wymienia się Bielika, Tapáka i Jakubiska.

[22] W filmie Bielika W piątek trzynastego (1953) również pojawiła się autoparodystyczna rola F. Dibarbory.
Jakie są źródła parodii filmowej, z którą zmierzył się Ťapák? Przede wszystkim trzeba stwierdzić, że jego film prezentuje humor ludzi najbardziej udręczonych, z dna drabiny społecznej. Człowiek, który nie może otwarcie się przeciwstawiać, broni się sprytem, zwinnością, przemyślnością. W legendach ludowych chłop pokonuje w ten sposób czarta, Cygan - gadżia, ubogi szewc - smoka. Parodia hiperbolizuje sfery, w których mogły się w jakiś sposób ujawnić, dać o sobie znać ewentualne krzywdy, niedostatki, kompleksy - niezależnie od tego, czy dotyczą one nierówności społecznych, czy zwykłych, codziennych spraw przeciętnego człowieka. Szczególnego znaczenia nabiera w filmie scena rozgrywająca się na dworze cesarskim. W szyscy skupiają się nad mapą imperium, by odnaleźć miejsce, z którego nadszedł list: „Tu Siedmiogród, tu Halicz, tutaj Galicja... Słowacja, Słowacja - gdzie to jest? Jakaś liptowska stolica?” Twarz jednego z dworzan nagle się rozjaśnia: „Wasza Wysokość, mamy tu jakichś murarzy, mniemam z liptowskiej stolicy“. W ten sposób twórcy ironizują na temat roli małego kraju w środku Europy. Rekompensatą owej podrzędności staje się atrakcyjność erotyczna Pacha, którego cesarzowa „chce za męża”. Odrzucone przez niego awanse uznaje za obrazę majestatu i depcząc mapę, krzyczy histerycznie: „Liptow, Hybe, wszystko zniszczę!”

Można również postawić tezę, że źródłem parodii są wcześniejsze filmy słowackie, zwłaszcza dzieła autorstwa długoletniej pierwszej gwiazdy tego kina - Palo Bielika. Hanáková zwraca uwagę, że Ťapák otwarcie parodiował jego perfekcję warsztatową, wykorzystywał identyczne plenery, sceny, zbójnickie fortele[20]. Rozmach kolejnych inscenizacji Bielika[21], pierwszeństwo w wykorzystywaniu kolejnych osiągnięć technicznych kinematografii słowackiej musiały budzić emocje w środowisku filmowym, być może i chęć ich parodiowania. Inspiracją mogły stać się parodie wprowadzone do filmów przez samego Bielika. Na planie jego filmu Ťapák widział parodystyczne role, w tym Františka Dibarborę[22] w rokokowym stroju sędziego; pomysł parodii rozwinął we własnym filmie, karnawalizując czy trawestując mit Janosika[23].
To może być ciekawy trop: niezwykle popularni w danym czasie aktorzy, wielcy reżyserzy (jak Bielik) i ich kult tak spowszednieją, że aż stają się znienawidzeni i proszą się o parodię.

[23] P. Hanáková, op. cit., s. 173. 
Scenariusz napisał z Peterem Jarošem. Milan Lasica i Július Satinský, zakazani w tym czasie, byli autorami dialogów. Czy przy tej współpracy udało się uzyskać jednolity charakter filmu i jakie jest jego przesłanie? Na ile różni się od przesłania filmu Bielika? W jego Janosiku padają pouczenia typu: „Cesarz jest niepotrzebny tak jak i wy. Ognie płoną na szczytach, to powiedzcie waszemu cesarzowi!" W scenie śmierci bohatera na horyzoncie płoną watry, a młodzi przysięgają na siekierę - tradycja walki klasowej nie zginie mimo śmierci przywódcy[24]. W finałowej scenie Pacha zakopany w ziemi po szyję bohater tytułowy (nasuwa się mimowolne skojarzenie z Que viva Mexico! Eisensteina) widzi trzech chłopców, którzy przyszli pobawić się na polanie. Kiedy próbuje ich przekonać, że nazywa się Pacho, nie wierzą mu. Jeden z nich twierdzi, że to on jest Pachem: wskakuje na skałę i z rozmachem strzela z bicza, niczym podobni do niego chłopcy uwiecznieni w filmie Plicki Ziemia śpiewa. Mimo parodystycznego charakteru - legenda o Pachu, który nie pozwolił się schwytać i zamknąć w Spielbergu, po raz kolejny okazała się silniejsza niż rzeczywistość. Młodym jest potrzebna właśnie ona. W drugiej połowie filmu jakby przypomniano sobie o źródle tejże legendy, czyli postaci historycznej i jej okrutnym końcu, który w istocie stał się początkiem legendy.

Legenda objawiała się regularnie w kluczowych momentach historycznych jako archetyp napełniany stale nowym znaczeniem, nowym wymiarem treści dramatycznej - mówi Peter Mihálik[25]. Autor zwraca uwagę na niezmiernie ważną rzecz: w swoich artystycznych reprezentacjach legenda dotychczas odzwierciedlała mechanizm wewnętrzny instynktu samozachowawczego narodu, ale i jego wysokie wartości moralne, odwagę przeciwstawiania się złu w chwilach decydujących. Powaga konceptu wykluczała dystans czy stylizację komediową. W zakończeniu historii Pacha twórcy jakby przestraszyli się całkowitego ośmieszenia tak poważnego tematu, dlatego przypomina ono swym tonem finał filmu Bielika.

Można spotkać się również z poglądem, że Pacho nie jest parodią, lecz nową postacią legendy, adekwatną do oczekiwań współczesnego widza. Zamiarem twórców było jej odświeżenie wzmacniającą dawką humoru. W jego wyniku powstała antylegenda zbójnicka, swobodna parafraza historii o mścicielach ludowych, która „bawi się bardziej na nasz własny rachunek niż na rachunek naszych przodków”[26]. Mimo zauważonych przez krytykę intencji „odświeżenia legendy” film nie przyczynił się do pobudzenia autorefleksji w wymiarze narodowym czy społecznym. Nie sprowokował wielkiego dyskursu o wartościach konstytuujących tożsamość.

Prasa $\mathrm{z}$ lat 70. donosiła, że w Humennym publiczność rozbiła żelazną bramę, by wejść na pokaz filmu. Pisano, że Słowacy się w nim odnaleźli, a każda replika okazywała się ich własną. Z punktu widzenia

[24] V. Macek, J. Paštéková, op. cit., s. 173.

[25] P. Mihálik, Paródia ako možnost’ vývinu, „Smena” 1976, 7 lipca, s. 6.
[26] Pacho, hybskýzbojník, Rôzne informačne materíaly [maszynopis], Slovenský filmový ústav, s. 31. 
tej publiczności pojawiła się komedia, od której w latach Husakowskiej normalizacji nie wymagano wszak zbyt wiele. Jeśli dopatrujemy się w niej jakichś wartości naddanych, to jest w tym zasługa autorów dialogów, których nazwisk nie można było w tym czasie wymieniać, oraz scenarzystów, którzy przepracowali legendę. Reżyserowi przyniósł wielką popularność (ponad 840 ooo widzów obejrzało film w kinach). Jego parodia odnosi się bardziej do Bielika jako „uznanej wielkości” niż samej legendy, przekazywanej słownie, której niuanse nie muszą być znane producentom filmowym. Mit Janosika sparodiowało bowiem już wcześniej samo kino, jego finansowe, później ideologiczne prawidła. Gdyby film o nim zrealizował w swoim czasie Karol Plicka, wizerunek bohatera nie stałby się zapewne „prawdziwy”, ale bliższy tradycji; ballada ludowa była najbardziej adekwatną formą, by wyrazić tak gruntownie poznany przez Plickę i bliski jego sercu temat. Odwołanie się do obrazu z jego filmu (chłopiec strzelający z bicza) przypomina o fundamencie kina słowackiego, który niesie wizję niezwykłej witalności narodu. Film Ziemia śpiewa, niekwestionowane arcydzieło, ma swój udział w utrwaleniu owej wizji. Wraca się do niego niczym do „mitu założycielskiego”, wywarł bowiem wpływ na całą generację filmowców. Mit Janosika[27], mimo „niechcianej” parodii, jakiej kino popularne może poddać każdy temat, jest nadal niezwykle użyteczny, czego dowodzi współczesna słowacka myśl polityczna[28]. Można powtórzyć - w duchu cytowanej na wstępie definicji - że mit jest wykorzystywany w celu ukształtowania myślenia, narzucenia takiego a nie innego programu i w warunkach słowackich niezwykłe jest to, że wciąż jest wyrazem społecznego, politycznego i kulturowego zapotrzebowania. Potrzeba mitu jest na tyle silna, że parodia filmowa nie byłaby w stanie go podważyć.

[27] Sama zaś legenda zbójnicka mimo prób jej oswojenia (w roku 1976 Viktor Kubal nakręcił pełnometrażowy film animowany Zbójnik Jurko) ma właściwość samoaktualizowania się w wymiarze nadzwyczaj poważnym, bo finansowym. Juraj Jakubisko wykorzystał legendę, by zrealizować reklamę (<http://www.youtube. com/watch?v=MFLkArEGtbs $>$ ), choć trzeba przyznać, że właśnie ta reklama przypomniała okoliczności pojmania legendarnej postaci. Niedokończona realizacja filmu o Janosiku w latach 9o. stała się na Słowacji powodem dyskusji publicznej i ostrej krytyki, ponieważ $\mathrm{z}$ kasy państwowej wypłynęło wówczas 80 mln koron.
[28] Podczas obchodów państwowych w styczniu 2008 roku premier Rober Fico ogłosił, że Juraj Janosik jest wielkim wzorem jego władzy. „Ponad tysiąc obecnych osób wszak się nie zaśmiało”. Podaję za: Fico: Jánošík je velký vzor mojej vlády, SMEsk [online], dostępny na stronie: <http://www.sme.sk/c/3659817/ fico-janosik-je-velky-vzor-mojej-vlady.html> [dostęp: 27 października 2013]. Nie był to jedyny przypadek, kiedy premier odwoływał się do Janosika jako - na przykład - pierwszego socjalisty. 